\title{
LATE PRECAMBRIAN GLACIOGENIC SEDIMENTARY ROCKS IN SOUTHERN AFRICA: A COMPILATION WITH DEFINITIONS AND CORRELATIONS
}

\author{
Alfred Kröner and Kalervo Rankama
}

\begin{abstract}
Alfred Kröner and Kalervo Rankama 1973 : Late Precambrian glaciogenic sedimentary rocks in southern Africa: a compilation with definitions and correlations. Bull. Geol. Soc. Finland 45, 79-102.
\end{abstract}

Evidence of ancient glaciations is summarized, and the terminology dealing with glaciogenic and nonglaciogenic sedimentary rocks is discussed. The term tillite is used as a comprehensive genetic term for both continentally deposited and ice-rafted indurated tills. The glaciogenic origin of any rock called tillite must have been proved beyond doubt. The term mixtite is used for sedimentary rocks that resemble tillites but are of uncertain or unknown origin.

A comprehensive compilation of all known Late Precambrian glaciogenic sedimentary rocks in South Africa and in South West Africa is presented. These rocks seem to form two distinct groups that may indicate the existence of two periods of glaciation. Glaciogenic rocks in other countries in Africa occupy similar stratigraphic positions. This evidence strengthens the possibility of the existence of a severe continentwide Late Precambrian glaciation in Africa. Comments on the Late Precambrian glaciation in Australia and in South America are given.

Alfred Kröner, Precambrian Researcb Unit, Department of Geology, University of Cape Town, Rondebosch, C.P., South Africa.

Kalervo Rankama, Institute of Geology and Mineralogy, The University of Helsinki, 00170 Helsinki 17, Finland.

\section{CONTENTS}

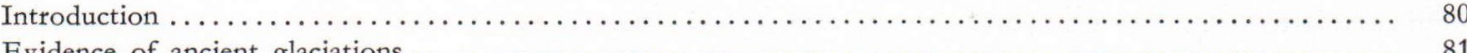

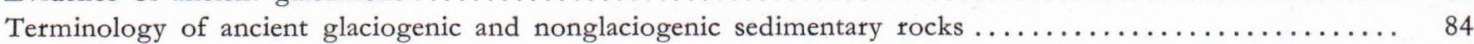

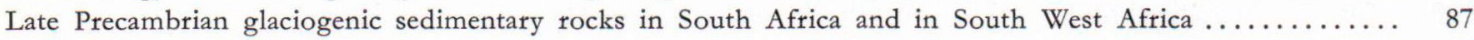

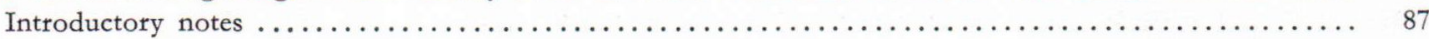




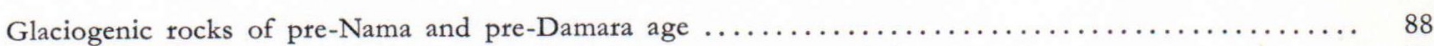

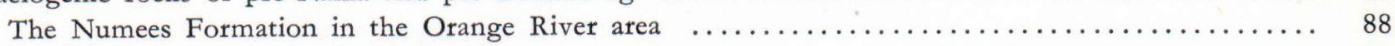

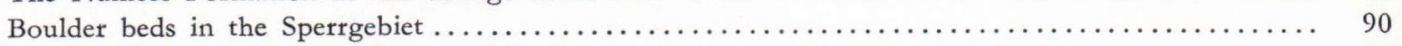

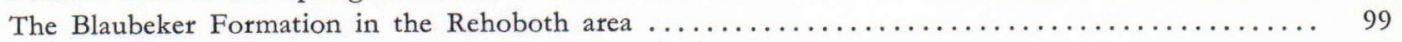

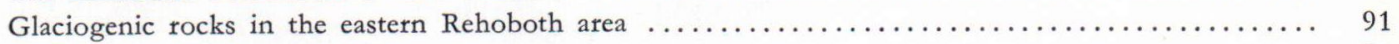

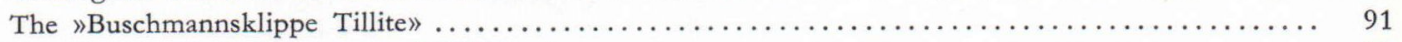

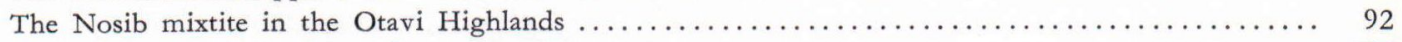

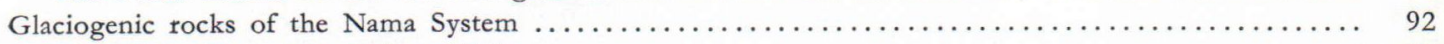

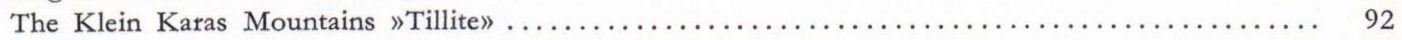

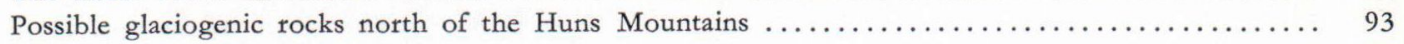

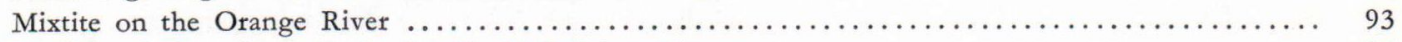

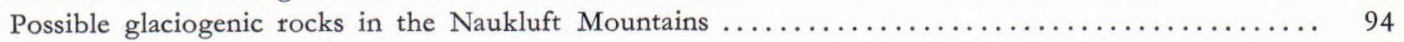

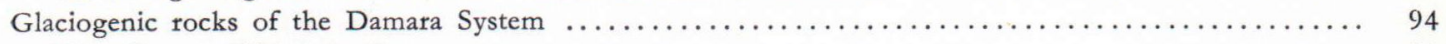

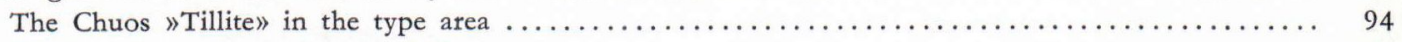

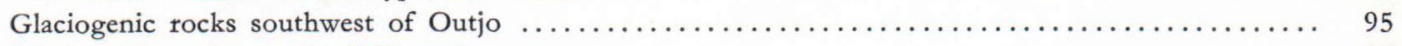

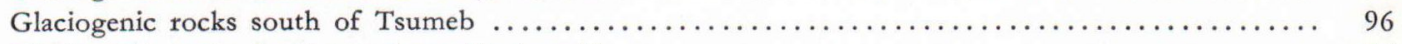

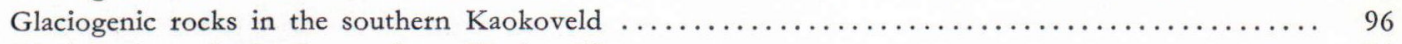

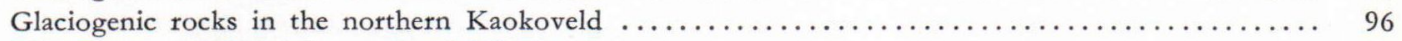

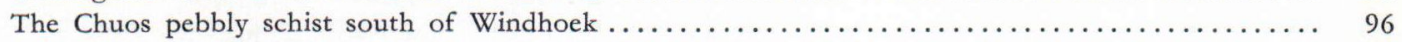

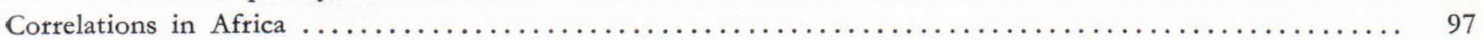

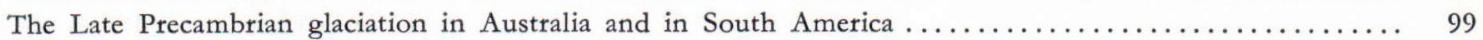

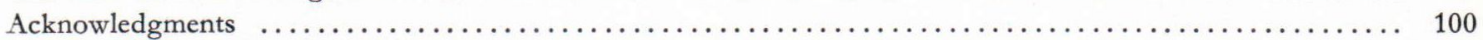

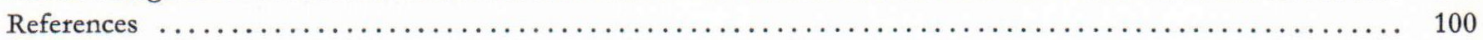

\section{Introduction}

A global glaciation is a major geologic event that marks the beginning of episodes of coldfacies sedimentation. There exists ample evidence of ancient glaciations, some of which took place early during the geologic evolution of the Earth. In fact, glaciations appear to be rather common events. Gowganda Glaciation, the most ancient among all known glaciations (Young, 1970), yields no evidence suggesting that meteorologic conditions and surface temperatures prevailing about $2.2 \mathrm{Ga}$ ago were very much different from those observed at present (Crowell and Frakes, 1970, pp. 194-195). In the identification and investigation of ancient glaciations, the principle of uniformity is applied, starting from observations made on the youngest, or Pleistocene, glaciation. This glaciation still continues, and almost certainly an interglacial interval now prevails (Crowell and Frakes, 1970, pp. 194, 211, 217). Glacial geologic and glaciologic observations made today give the geologist they key to the study of ancient glaciations.

The increasing interest in the Precambrian, grown rapidly during the past ten years or so, has produced a vast store of new information about Precambrian glaciations (Harland, 1964, 1965; Young, 1970; Dunn, Thomson, and Rankama, 1971; Spencer, 1971). From time to time, strong opinions for and against the existence of glacial conditions late in the Precambrian have been expressed, based on the interpretation of the pertinent sedimentary rocks as glaciogenic or nonglaciogenic. Geomagnetic evidence has also been used, with results conflicting with geologic interpretations. Much recent interest has been directed toward the youngest Precambrian glaciation, widely recorded in both the Northern Hemisphere and the Southern Hemisphere. The Late Precambrian glaciation took place about 750 $\mathrm{Ma}-600 \mathrm{Ma}$ ago. It is unanimously accepted as one of the outstanding and exceptional global physical events in the history of the Earth. It is 
believed to have been longer than any of the Phanerozoic glaciations, covering, as it did, a time span of about $100 \mathrm{Ma}-150 \mathrm{Ma}$ or, perhaps, some hundreds of millions of years (Harland, 1964 , pp. 123, 124). It also seems to have been of a more severe climate than any of the ensuing Phanerozoic glaciations (Nairn, 1964, p. 113; Harland, 1965, p. 57; Dunn, Thomson, and Rankama, 1971, p. 498). It has been concluded that by no means all the pertinent glaciogenic rocks are exactly contemporaneous (King, 1961, p. 313; Schwarzbach, 1961, p. 258), and the worldwide synchroneity of the Late Precambrian glaciation has been questioned (Crawford and Daily, 1971, p. 112). However, the glaciogenic rocks indicate that some parts of Gondwanaland at least had a frigid climate at any one time during the glaciation, while the climate may not have been frigid for the supercontinent as a whole (King, 1961, p. 313). The glacial ages, or the maxima of glaciation, in the Northern Hemisphere and in the Southern Hemisphere were not necessarily synchronous (Harland, 1964, pp. 123, 129; Crowell and Frakes, 1970, p. 204; Dunn, Thomson, and Rankama, 1971, p. 498).

A special reason for the interest in the Late Precambrian glaciation is its possible use as a worldwide stratigraphic boundary for the stratigraphic subdivision of the Late Precambrian. This possibility has been discussed on the basis of the well exposed and well documented Late Precambrian glaciogenic rocks in Australia, primarily in order to establish a chronostratigraphic unit for use in that continent (Dunn, Thomson, and Rankama, 1971). However, Crawford and Daily (1971, p. 112) expressed doubts as to the suitability of tillites for the subdivision of Precambrian time.

The study of glaciations and glaciogenic rocks predating the Pleistocene is rendered difficult by much confusion that prevails about the terminology used for glaciogenic sedimentary rocks and other rocks resembling them. In some parts of the Southern Hemisphere, it has been customary to use the term tillite for sedimentary rocks the manner of formation of which could not be readily explained (Nairn, 1964, p. 78). Moreover, pebbly sedimentary rocks of unknown origin or of doubtful parentage, such as pebbly mudstones, are often indiscriminately called tillites (Schermerhorn and Stanton, 1963, pp. 202-203; Schermerhorn, 1966, p. 832). The evidence of former glaciations, the identification of sedimentary rocks formed during them, and the terminology of such rocks have been discussed by many specialists (Flint, 1961; Harland, Herod, and Krinsley, 1966; Flint, 1971). Textural-genetic classifications, some of them rather complicated, have been proposed (Harland, Herod, and Krinsley, 1966).

The purpose of this paper is to summarize the evidence of ancient glaciations, to discuss the terminology dealing with glaciogenic and nonglaciogenic sedimentary rocks, to review Late Precambrian glaciogenic sedimentary rocks in South Africa and in South West Africa, and, finally, to correlate the Late Precambrian glaciogenic sedimentary rocks in southern Africa, with notes on their general correlation in the Southern Hemisphere.

\section{Evidence of ancient glaciations}

Evidence of ancient glaciations is based on geologic observations. Features indicative of prePleistocene glaciations that may be assumed to be preserved in the geologic column are based on glacial abrasion, transportation, and deposition; accumulation of sediments in a cool or cold climate; and deposition of glacial-marine sediments on the bottom of the sea. Not all features of glacial activity will be indefinitely preserved throughout geologic time, and it is not always easy to prove that rocks attributed to a glaciation are really glaciogenic (Harland, 1964, p. 120; Schwarzbach, 1964, p. 82). Glaciated pavements in bedrock - furrowed, grooved, striated, and polished - formed by the action of drift-shod ice are a very important criterion (Schwarzbach, 
1964 , p. 82) but do not always constitute reliable evidence of glaciation, unless they are very extensive areally and are supported by associated unequivocally glaciogenic features, such as glacial quarrying; whaleback forms; stoss-and-lee forms; and tillite, possibly with preserved till fabric, that almost always accompanies glaciated rock surfaces (Flint, 1961, pp. 142-143; Crowell, 1964, pp. 87-88; Heezen and Hollister, 1964, p. 99).

Tillite, a sedimentary rock, is consolidated till produced by an ancient glaciation. It is generally regarded as the most reliable evidence of ancient glaciations (Flint, 1961, p. 154). The reader is referred here to the critical and detailed discussion, by Harland, Herod, and Krinsley (1966, pp. $240-251$ ), of criteria and evidence for the definition and identification of tillites, based on a comprehensive survey of pertinent literature. Tillite is dominantly nonsorted indurated drift. Its clasts have a wide range of grain sizes and possess no definite lithologic composition. It has been claimed that ancient tillites are unlikely to be accompanied by much stratified sedimentary rock originated as outwash sediments (Flint, 1961 , p. 147). This claim is not valid because it is known that the Dwyka Tillite is accompanied by a large amount of stratified sedimentary rock regarded as outwash. The complete absence of sorting is considered to suggest origin as till (Harland, Herod, and Krinsley, 1966, p. 241). The pebbles and cobbles in tillite are not rounded, but some may have abraded faces and polished surfaces, and possess striations (Flint, 1961, p. 144; D. R. Crandell, quoted in Denton and Armstrong, 1969, p. 1129). Under appropriate conditions, striations on clasts are believed to be so definitive that their presence is one of the most important criteria for glaciations, while their absence does not necessarily oppose a glacial origin (Harland, Herod, and Krinsley, 1966 , p. 247). A characteristic fabric, like that in till, may be present (Harland, 1965, p. 48). However, very few deposits of tillite meet all the criteria (Denton and Armstrong, 1969, p. 1127). The surface textures of sand grains in tillites, as observed under the electron microscope, may also give clues as to the environment of sedimentation (Harland, Herod, and Krinsley, 1966, pp. $247-248)$.

The thickness and extent of Precambrian tillites are variable. Martin (1965 b, pp. 28, 99) reported a thickness of up to $600 \mathrm{~m}$ for the Late Precambrian Chuos and Numees Tillites in South West Africa. Dunn, Thomson, and Rankama (1971, p. 501) reported a maximum thickness of about $5500 \mathrm{~m}$ for tillite and glacial-marine sedimentary rocks of the Sturtian Glaciation in Australia. Spencer (1971, p. 6) gave the thickness of the assumedly Late Precambrian Port Askaig Tillite sequence in Scotland as $750 \mathrm{~m}$.

It is known that extensive deposits of till form also in a marine environment by melting from floating ice that may travel great distances (for instance, the Dwyka Tillite of the Karoo System). Such tills cannot be distinguished from continental tills (Harland, Herod, and Krinsley, 1966, pp. 232, 234), except that the continental tills may lie on glaciated pavements. Consequently, it may be expected that among ancient tillites there occur also marine ones.

Till entombed in marine sediments is most likely to be preserved (Crowell, 1964, p. 88). However, it is necessary to prove beyond doubt that an assumed tillite is really glaciogenic, because till-like sediments are known to form by many other geologic agents. Many conglomerates and pebbly mudstones in various parts of the world have been mistaken for tillites. Such sedimentary rocks, occurring as masses, lenses, or beds, were originally formed by downslope movements caused by subaerial and submarine mudflows and slumping and turbidity currents, as fluvial sediments, and by mixing of coarse clasts with finer-grained material (Schermerhorn and Stanton, 1963; Crowell, 1964, pp. 87, 91-94, 97-99; Heezen and Hollister, 1964; Harland, Herod, and Krinsley, 1966, pp. 237-239; Schermerhorn, 1966). Flint (1961, pp. 148-149; 1971, pp. 152-153) published useful tabulations showing the characteristics of tillites and tillite-like 
sedimentary rocks. In addition to tillites proper, ancient glaciogenic sedimentary rocks may possibly also consist of some indurated stratified drift, deposited in the immediate vicinity of glacier ice, or of consolidated glacial-fluvial outwash sediments, mainly sand and gravel (Flint, 1961, p. 147; 1971, pp. 183-186), and of glacialmarine deposits.

Boulton (1972) felt that existing models for the interpretation of ancient tills and till-bearing sequences are often too simple. In his opinion, till is too often interpreted solely as lodgment till, and inadequate attention is paid to the existence of tectonic structures in till and to the retreat of glaciers.

Recognition of tillites provides the essential evidence for postulating ancient glaciations (Flint, 1961, p. 147; Harland, Herod, and Krinsley, 1966, p. 227). If an ancient nonsorted sedimentary rock is suspected of being tillite, all its internal features, lithologic and petrographic properties, and stratigraphic and regional relations must be studied, alternative origins must be eliminated one by one, and positive identification as tillite should be made only after the other possible origins have been rendered extremely improbable (Flint, 1961, p. 147; Crowell, 1964, p. 93; Harland, 1964, p. 120; Winterer, 1964, p. 173).

Heezen and Hollister (1964, pp. 100-101) concluded that confusion of tillites and turbidites should not exist because of the great difference between the two types of sedimentary rocks. Tillites are nonstratified, nongraded, nonsorted, and structureless sedimentary rocks, whereas turbidity-current deposits are distinctly stratified, graded, and moderately well sorted. They have abundant flow marks, scour marks, and flow casts on their lower bedding surfaces. Conversely, tillites are similar to sedimentary rocks originated as mudflow deposits, and Heezen and Hollister felt that it is impossible to distinguish a tillite from a mudflow deposit except for the glacial markings associated with tillites; some of the glacial criteria might conceivably be produced also by mudflows. Turbidity currents are very often associated with glaciations, but this association is not necessary. Harland (1964, p. 120) stated that the occurrence of allochthonous clasts, in widespread variable deposits, at a distinct stratigraphic horizon, or horizons, is often a decisive criterion for glaciogenic origin, when there exists no evidence of contemporaneous deposition slopes or of deformation. However, ice-rafted material may also be present in turbidites.

Harland, Herod, and Krinsley (1966, pp. 225, 239), however, felt that the deposition of nonsorted and nonstratified sediments by various mass-flow processes might cause confusion as to the glaciogenic or nonglaciogenic origin of such sediments and of the corresponding sedimentary rocks. Mudflows and turbidity currents are likely to occur more frequently during glacial than nonglacial ages.

Pleistocene glaciogenic strata contain "varved» clays, that is, fine-grained bottom sediments of some glacier-margin lakes, or glacial lakes. They are rhythmically laminated (Flint, 1961, pp. 147, 150; Heezen and Hollister, 1964, p. 103; Flint, 1971, p. 194). The existence of pre-Pleistocene sedimentary rocks, consisting of fine-grained rhythmically laminated layers similar to the "varved" clays, has also been considered evidence of ancient glaciations. If such rhythmites occur with tillite, it is more probable that they are glaciogenic rather than produced by turbidity currents (Flint, 1961, p. 150), but this evidence has been considered circumstantial (Schwarzbach, 1964, p. 85). Some marine turbidites may also simulate varves (see also Harland, Herod, and Krinsley, 1966, p. 239).

Stones and boulders transported by ice even for hundreds of kilometers afford additional evidence of ancient glaciations. They are erratics, erratic clasts, or exotic boulders, that differ lithologically from the country rocks in the area where they occur. Erratic clasts, rafted by floating ice, occur in indurated bottom sediments of glaciermargin lakes, and till-like deposits, originally derived from grounded icebergs, may lie upon or 
between lake-floor sediments (Flint, 1971, p. 194). It is possible that there exist corresponding ancient tillite-like sedimentary rocks.

Glacial-marine sediments deposited beneath Holocene floating glaciers and ice shelves, and by icebergs and sea ice, are generally widespread on and beneath the sea floor (Flint, 1971, p. 195). Glacial-marine sedimentary rocks, originally deposited on the deep-sea bottom, serve as one of the best indications of the existence of glaciated continental areas in the neighborhood. The original sediments are typically normal marine lutites and contain isolated ice-rafted clasts and disseminated sand and silt. They contain also lentils of sorted and stratified sedimentary material, chiefly sand. The clasts are usually rounded and commonly faceted and striated (Crowell, 1964, p. 87; Heezen and Hollister, 1964, p. 99; Flint, 1971, p. 196).

Debris dropped by floating ice is likely to be preserved for long periods and is areally widely distributed. The existence of thin deformed and disturbed laminated sedimentary beds surrounding a megaclast, especially in geosynclinal basins with a rapid sedimentation, offers compelling evidence that the clast was dropped from floating ice (Crowell, 1964, pp. $87-88,93,97)$. It is agreed that evidence of rafting afforded by the presence of megaclasts in a fine-grained stratified sedimentary rock is, even alone, with some qualifications, decisive proof for the recognition of the rock as glaciogenic (Harland, 1965, p. 49; Harland, Herod, and Krinsley, 1966, pp. 225, 243). A clast pointed perpendicular to lamination, such as the boulder that Martin (1965 a, pp. 121 -122) described, could not easily have slid sideways into that position (Harland, Herod, and Krinsley, 1966, p. 243).

Harland, Herod, and Krinsley (1966, p. 249) emphasized the importance of the overall extent of glaciogenic deposits, noting that tillites originally deposited as ice-rafted tills may extend over hundreds of thousands of square kilometers, even though, timewise, they may be infrequent in a sedimentary sequence.
Ancient glacial and glacial-fluvial morphologic forms, such as various moraines and eskers, and sediments created by frost action, have little chance of preservation and consequently are not important for the identification of pre-Quaternary glaciations. It is also agreed that glacial-fluvial material cannot be distinguished from normal fluvial material (Heezen and Hollister, 1964, p. 100; Schwarzbach, 1964, p. 84). However, Spencer (1971, pp. 40, 51) described what he claimed to be the first known pre-Pleistocene sedimentary rocks created by frost action, inferred to be polygonal sandstone wedges formed by frost contraction, in the Port Askaig Tillite sequence in Scotland, presumed to be Late Precambrian.

Summarizing their discussion of criteria for glacial origin of sedimentary rocks, Harland, Herod, and Krinsley (1966, p. 251) concluded that the presence of numerous large clasts penetrating and deforming a series of host strata is a decisive criterion that can be used alone. Stratigraphic evidence as such is not decisive, unless supported by other evidence, and the shape, surface features, size, and lithologic composition of clasts require careful interpretation, as does also the presence of pavements. They were sceptical as to the use of mechanical analysis or fabric analysis as a criterion. However, the occurrence of large clasts of varied composition in any environment in itself suggests glacial transport. Nonglacial phenomena, such as mudflows and turbidity currents, may confuse arguments for glacial origin but do not argue against it. Finally, they stated that such phenomena are likely to occur more frequently during glacial ages than during nonglacial ages.

\section{Terminology of ancient glaciogenic and non- glaciogenic sedimentary rocks}

There exists a rather confusing terminology for glaciogenic and nonglaciogenic sediments and sedimentary rocks. Schermerhorn and Stanton 
(1963, pp. 202-203) suggested that the term tillite, being a genetic one, should be used only for rocks that have been proved glaciogenic beyond doubt. True tillites, in addition, were originally terrestrial deposits, but glacial-marine sedimentary rocks that contain ice-rafted material may be tillite-like in appearance and have been incorrectly called tillites. Flint (1971, p. 196) also pointed out that glacial-marine sediments are not to be considered till, a term restricted to terrestrial sediments. Schermerhorn and Stanton used the term tilloid for nonglaciogenic sedimentary rocks that resemble tillites in appearance, such as pebbly mudstones, pebbly and bouldery graywackes, and calcarenites. Discussing their paper, W. B. Harland (in Schermerhorn and Stanton, 1963, pp. 239-240) applied the term tillite to both continental and marine glaciogenic sedimentary rocks, suggesting the terms continental tillite and marine tillite to distinguish the environment of deposition, if required. $\mathrm{He}$ argued that tillite - tilloid is not a useful antithesis.

Schermerhorn (1966, p. 834) proposed the term mixtite as a descriptive and qualitative nongenetic group name for nonsorted or ill-sorted clastic sedimentary rocks that contain megaclasts, without regard to lithologic composition or origin. He (Schermerhorn, 1966, p. 832) also suggested the name aquatillite for glacial-marine and glacial-lacustrine sedimentary rocks with a lithologic composition similar to that of tillite.

Harland, Herod, and Krinsley (1966, pp. 231 -234) published a textural-genetic classification of tills, tillites, and related rocks, including tilloids and pseudotillites, and discussed in detail their petrographic and petrogenetic aspects. Their classification is very complicated. They defined orthotillites as tillites derived from orthotills, or tills formed by immediate release from transporting ice. They suggested the name paratillite for tillites that originated as paratills, that is, as tills deposited by ice rafting in a marine or a lacustrine environment. These names, like allochthonous and autochthonous tillites, and derived tillites, appear superfluous because of difficulties in unraveling the exact manner of formation of tillites, and they complicate the terminology unnecessarily. They (Harland, Herod, and Krinsley, 1966, p. 229) suggested diamict as a comprehensive general term for sediments and sedimentary rocks, including tillites, with a wide range of particle sizes.

The term diamictite was originally proposed for nonsorted terrigenous sedimentary rocks containing a wide range of particle sizes, regardless of their manner of formation (see Flint, 1971, p. 154).

In our opinion, only two terms are necessary, namely, a term for ancient glaciogenic sedimentary rocks and another term, a general one, for sedimentary rocks that resemble glaciogenic ones but are of uncertain or unknown origin. Following Flint (1971, p. 148), we define tillite as indurated till. Consequently, tillite is a genetic term, and its use implies that the glaciogenic origin of any rock called tillite has been proved beyond doubt. Thus, we also accept the argument of Schermerhorn and Stanton (1963, p. 202). Because of difficulties in solving the problem of the original sedimentation environment, we prefer to make no difference between continentally deposited and ice-rafted indurated tills. We agree with Harland (1965, pp. 47-48) in that a substantial component of the original sediment was transported by ice on land or on, generally, sea water, or on both.

Harland, Herod, and Krinsley (1966, p. 228) regarded tills and tillites as sediments. However, in lithologic parlance, tillite is a sedimentary rock (consolidated), whereas till is a sediment (unconsolidated).

There exist also metamorphosed tillites that are conveniently called metatillites (Harland, Herod, and Krinsley, 1966, p. 228).

As to the general term, diamict is unsatisfactory because it includes both sediments and sedimentary rocks, and diamictite is not satisfactory because it refers only to terrigenous glaciogenic deposits and thus excludes glacialmarine deposits. Similarly, the term tilloid is not 


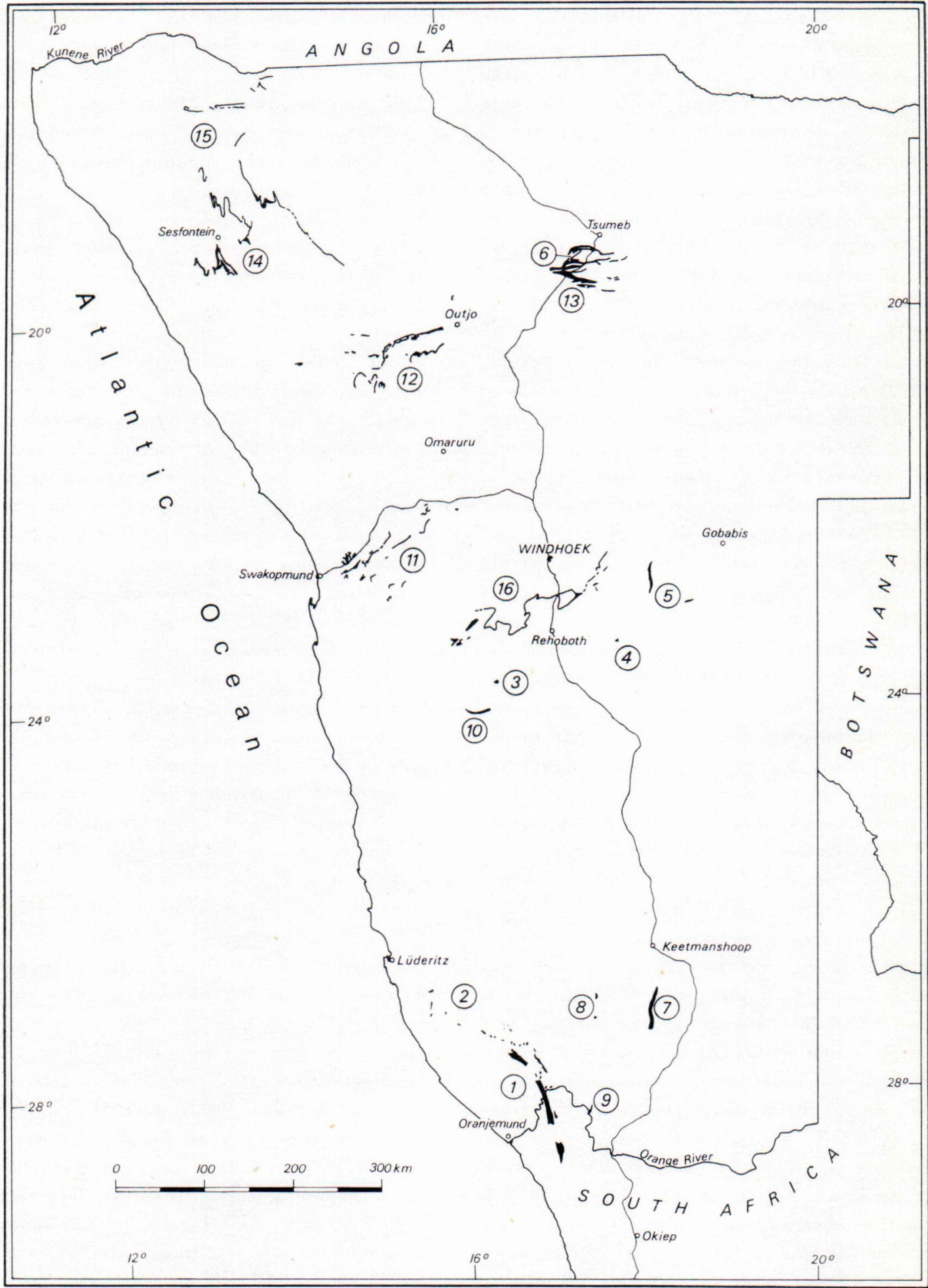

Fig. 1. Distribution of Late Precambrian glaciogenic sedimentary rocks in South West Africa. Numbers refer to areas or localities described in the text. 
satisfactory. Firstly, tilloids are nonglaciogenic rocks that resemble tillites in appearance, according to the definition given by Schermerhorn and Stanton (1963, p. 203). Secondly, as Harland, Herod, and Krinsley (1966, p. 233) pointed out, tilloid means till-like. They, however, used this term for both tills and tillites of doubtful origin. We cannot endorse this usage and suggest the use of the term tilloid, if at all, only for sediments, not for sedimentary rocks. This is also etymologically correct. ${ }^{1}$ They also endorsed the term pseudotillite for tillite-like rocks found to be nonglaciogenic. This term is also superflous because certainly a tillite-like rock found to be nonglaciogenic deserves a proper lithologic name.

As a general term, we propose to use mixtite for tillite-like rocks of uncertain or unknown origin. If proved to be glaciogenic, they are properly called tillites. Mixtite is the general term proposed by Schermerhorn (1966) and has already been used as a general nongenetic term (Spencer, 1971, p. 2).

\section{Late Precambrian glaciogenic sedimentary rocks in South Africa and in South West Africa}

\section{Introductory notes}

The western part of southern Africa contains a wealth of Precambrian sedimentary rocks that include mixtites, frequently described as tillites in the past. Until recently, the age relationships

1 In Webster's Seventh New Collegiate Dictionary, the suffix "-oid", as noun, is defined as something resembling a (specified) object or having a (specified) quality.

2 The term» System" has been used in South Africa as a lithostratigraphic unit. The Geological Survey of South Africa has not accepted the definition of a System as a chronostratigraphic unit as proposed by the International Subcommission on Stratigraphic Classification (Hedberg, 1972).

Although we do not agree with the present South African connotation of the term, it is used in this paper to avoid confusion with the older literature.

The stratigraphic nomenclature is at present being revised. The Gariep has already become a Group (Kröner, 1971, p. 1519), and the Nama and the Damara will eventually also become Groups.

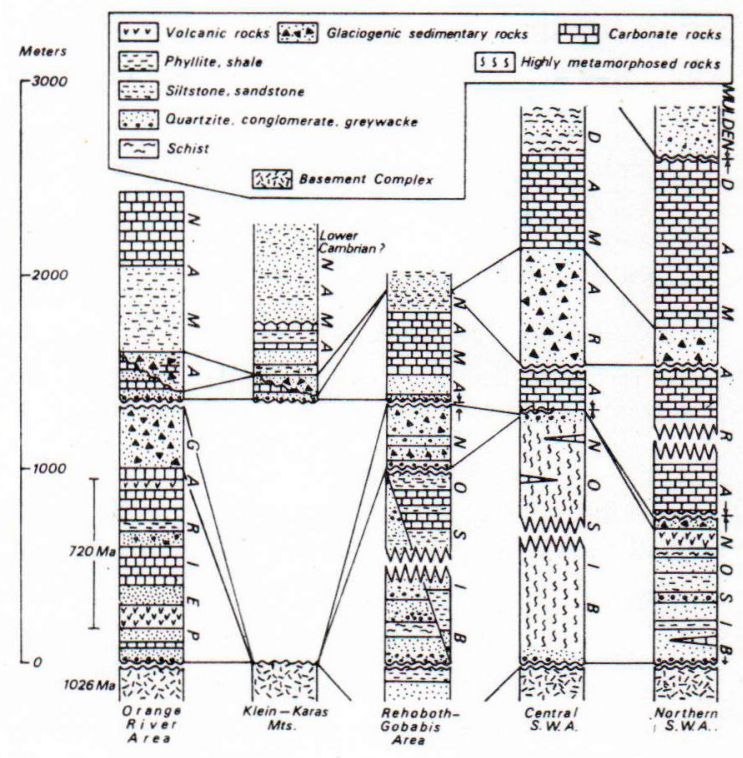

Fig. 2. Stratigraphic succession and suggested correlation of Late Precambrian rocks in South West Africa.

among the various glaciogenic sedimentary rocks have been rather uncertain, and it appeared that several glaciations of only local importance had taken place during a time span of several hundred million years.

Martin (1965 a) first recognized that all these glaciogenic rocks were probably deposited during Late Precambrian time. He (Martin, 1965 b, pp. 115-120) attempted a correlation among the Damara, Nama, and Gariep Systems, ${ }^{2}$ using the mixtite beds as marker horizons.

Germs (1972, p. 68) found evidence of fairly widespread glacial conditions during Nama time. Schalk's (in press) results indicate that it is now possible to correlate the Nama and Damara Systems (Kröner, 1971, p. 1521). Furthermore, Kröner (1971, p. 1520) suggested the correlation of the Gariep beds of the Orange River area with the Nosib succession of central and northern South West Africa.

Recent evidence thus suggests that two distinct periods of glaciation occurred during Late Precambrian time. This evidence will be discussed in the sections to follow. Figure 1 shows the distribution of glaciogenic sedimentary rocks discussed in this paper, and Figure 2 shows the pro- 
posed stratigraphic correlations of the glaciogenic rocks.

\section{Glaciogenic rocks of pre-Nama and pre-Damara age}

The Numees Formation in the

Orange River area

Precambrian glaciogenic sedimentary rocks were first described in western South Africa from the Richtersveld (No. 1 in Fig. 1) in the northwestern part of Cape Province (Rogers, 1915). This sequence, called the »Numees Series», was later investigated in detail by de Villiers and Söhnge (1959) who, following Rogers, correlated their Numees Formation with the Griquatown Series of the Transvaal System. Martin (1965 a; 1965 b, p. 105) first recognized the Late Precambrian age of the Numees beds when he noted their occurrence north of the Orange River. McMillan (1968) gave a detailed account of the Numees strata between the Orange River and Witputs. All these geologists called the glaciogenic sedimentary rocks tillites, and the Numees Formation has since been regarded as the bestexposed evidence for a Late Precambrian glaciation in southern Africa.

One of us (A. K.) reinvestigated the Orange River area and found that only a part of the sequence called the Numees Formation may be glaciogenic (Kröner, in preparation; see Fig. 2). We visited several Numees outcrops during a field trip in February, 1971.

In the Richtersveld, the Numees mixtite is exposed in a narrow $\mathrm{N}$-S-striking synclinorium and lies conformably upon older strata of the Gariep Group (see Fig. 2). Its maximum thickness has been estimated as $600 \mathrm{~m}$ (de Villiers and Söhnge, 1959, p. 149), but strong deformation has affected the strata, and there may be some repetition caused by folding.

The color of the matrix ranges from dark green to grey, and the matrix is usually iron-rich and varies from fine-grained schistose to gritty or arkosic. The clasts are of all sizes and shapes, but well-rounded clasts ranging from $5 \mathrm{~cm}$ to $30 \mathrm{~cm}$ in diameter predominante. Boulders up to nearly $3 \mathrm{~m}$ in diameter and numerous faceted and striated clasts have been observed (de Villiers and Söhnge, 1959, p. 149). The clasts consist almost exclusively of various basement gneisses and granites, those derived from Gariep strata being extremely scarce or absent.

Thin lenticular layers of dolostone, shale, and, sometimes, gritty or pebbly quartzite are interspersed throughout the mixtite, but in many places the rock is massive and apparently unbedded. A thin layer of banded ironstone occurs frequently at the base. Strong deformation within the Numees Synclinorium gave rise to a conspicuous steeply dipping foliation in the rocks, and most clasts were rotated and subsequently flattened during this process.

North of the Orange River the mixtite attains a thickness of up to $1000 \mathrm{~m}$, but the sequence may be partly repetitious as a result of slumping, folding, and faulting. Deformation has often concealed original sedimentary features, and the glaciogenic origin of the sequence is often doubtful. However, laminated shales resembling varved sediments near the top of the sequence were sufficient evidence for Martin (1965 a, p. 123) to regard the boulder beds as tillites.

On the farm Trekpoort, northwest of Rosh Pinah, another exposure of mixtite attains a thickness of $90 \mathrm{~m}$ on the Koivib Mountain. Wellsorted indurated gravel beds are overlain by laminated shale containing dropstones and by gritty quartzite and blue-black shale. This sequence is overlain by dark massive mixtite that contains unsorted erratics and displays a faint bedding at several places.

East of Rosh Pinah about $40 \mathrm{~m}-50 \mathrm{nl}$ of Numees mixtite is exposed on the Namuskluft escarpment. This rock contains abundant clasts of dolostone, along with many clasts of basement granite and gneiss. Several well-preserved layers, up to $40 \mathrm{~cm}$ thick, of dolostone slump breccia occur in this sequence, and more contorted fragments of dolostone breccia are scattered throughout the otherwise unbedded mixtite. It is sug- 
gested that most, if not all, dolostone erratics were probably derived from stromatolite reefs that disintegrated during gravity slumping and were subsequently incorporated in the mixtite. A giant dolostone boulder, measuring $11 \mathrm{~m}$ by $2.5 \mathrm{~m}$ by $1.5 \mathrm{~m}$ (Martin, $1965 \mathrm{~b}$, p. 101), may have been transported in a similar manner.

Sedimentary rocks described as tillites of the basal Numees Formation (McMillan, 1968, p. 85) are in fact basal conglomerates of the Gariep Group, with exposures extending from Namuskluft via Witputs into the Sperrgebiet (see p. 90). Even though they are at places strikingly similar in appearance to some Numees mixtites, their nonglaciogenic origin is, nevertheless, clearly demonstrated (Kröner, in preparation).

No glaciated pavement is present under the Numees mixtite, because the Numees overlies the older Gariep beds conformably, often with a gradational contact.

It appears from the description presented above that the Numees glaciogenic sediments were never deposited as till. The general roundness of the clasts; partial stratification of the deposit, with locally preserved cross-bedding and graded bedding; dolostone and quartzite intercalations; and laminated shales all suggest glacial-marine deposition. The presence of erosion channels (McMillan, 1968, p. 88) indicates fluvial-glacial or merely fluvial origin in places.

Martin (1965 a, p. 123) regarded varved shales with dropped-in clasts in small basins near the Numees Synclinorium as sufficient evidence for the glaciogenic origin of the boulder beds (see Fig. 3). However, during Numees time, the basins may have contained lakes that had a frozen surface in winter. Clasts of various sizes may then have been washed onto the ice by spring meltwaters, and when the ice melted, the material dropped to the bottom. This mechanism explains why certain layers of the laminated shales are studded with clasts while others are devoid of them.

Near Annisfontein in the Richtersveld, a stromatolite reef was found to have grown simul-

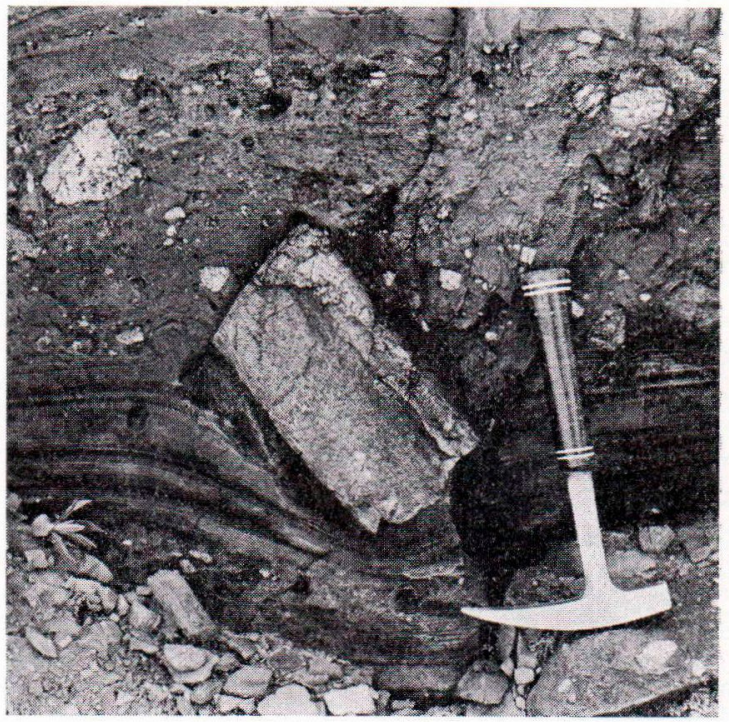

Fig. 3. Laminated siltstone with a dropped-in angular clast of gneiss. A small basin near Witputs, South West Africa. Photo Alfred Kröner.

taneously with the deposition of Numees sediments, and immediately south of the Orange River well-bedded arkosic quartzites and conglomerates grade into mixtite along their strike. These features are strong evidence against glaciogenic origin, but undoubted faceted and striated clasts also occur. It is therefore likely that the original glacial-marine sediments were extensively reworked shortly after their deposition on a tectonically unstable floor and that synsedimentary gravity slumping, ubiquitous throughout the Gariep strata (Kröner, in preparation), may have had an important part in this process.

All available evidence suggests that most of the Numees mixtites are turbidites in which glaciogenic material became incorporated. A similar origin has been suggested for the Late Precambrian "tilloids» in Angola (Rhodes Fairbridge, discussion in Schermerhorn and Stanton, 1963, p. 235).

It follows from the descriptions presented above that the term tillite, as defined on p. 85, cannot be applied to any of the Numees sedimentary rocks. 
Boulder bedsin the Spergebiet

Exposures of rocks assigned to Numees Tillite in the Witputs area (Martin, 1965 b, p. 101; McMillan, 1968, p. 78) extend to the northwest into the Sperrgebiet where outcrops are particularly good in the Klinghardt Mountains and near the Kaukausib waterhole (No. 2 in Fig. 1).

The sequence consists of conglomerates locally containing boulders with a diameter of up to $3 \mathrm{~m}$ and reaching a thickness of up to $60 \mathrm{~m}$. They are overlain by, and frequently interbedded with, grits, siltstones, dolostones, and shales, all of variable thickness (see Fig. 4). Facies changes along the strike are common. The well-rounded clasts in the basal boulder beds consist exclusively of granite, gneiss, metaquartzite, and various schists, all derived from the underlying basement, and the clasts are often so closely packed that the matrix, ranging from gritty to arkosic, constitutes only $10 \%$ by volume of the rock or even less. Graded bedding is ubiquitous throughout the sequence (see Fig. 4).

Field work carried out by one of us (A. K.) indicates that the rocks described are not glaciogenic. Evidence for this conclusion will be given elsewhere (Kröner, in preparation). Excellent

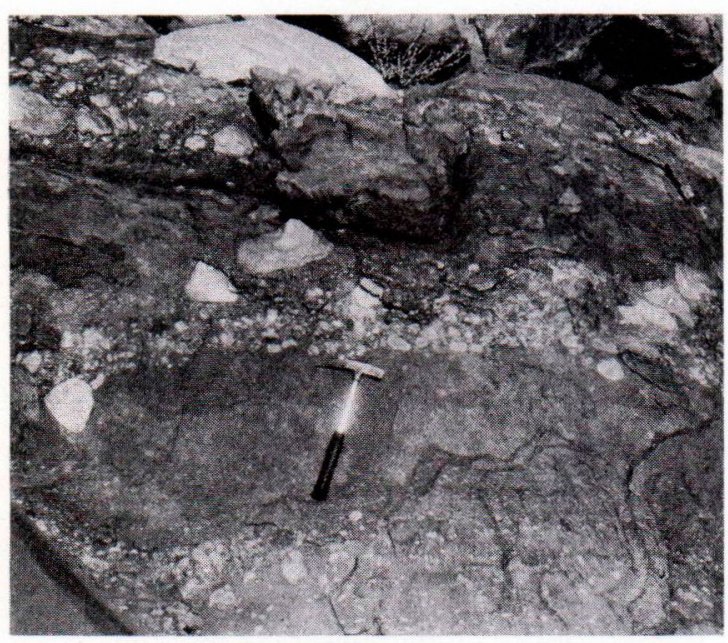

Fig. 4. Well stratified mixtite showing graded bedding. Basal conglomerate sequence of the Gariep Group in the Sperrgebiet, South West Africa. Photo Alfred Kröner. outcrops near Kaukausib show that the conglomerate has been subjected to considerable slumping at many places, giving rise to mudflowlike features, readily misinterpreted as being glaciogenic.

The Blaubeker Formation in the Rehoboth area

Clastic sedimentary rocks of probable glaciogenic origin crop out on the farms Blaubeker, Lepel, Garies Oos, and Garies Wes in the Rehoboth area (No. 3 in Fig. 1; Schalk, in press). The rocks overlie unconformably the Kamtsas quartzites of the Nosib succession (see Fig. 2), but they are lithologically remarkably similar to the Nosib sedimentary rocks, suggesting similar conditions of deposition from the Nosib time to the Blaubeker time with, possibly, only a short hiatus between the two units. The glaciogenic rocks are, in turn, unconformably overlain by rocks of the Nama System (see Fig. 2).

The Blaubeker succession begins with a wellbedded pebbly quartzite that contains rounded clasts of felsic porphyry, quartz, granite, and metaquartzite. Angular clasts of the Kamtsas quartzite are also present, suggesting reworking of the unconsolidated pre-Blaubeker strata. At some places within the succession, there occur greenish quartzites and sandy slates free of clasts.

The upper part of the Blaubeker Formation consists of "thick, very coarse conglomerates which are mainly developed as tilloids» (Schalk, in press). The greenish-grey matrix is fine-grained and unstratified and contains irregularly distributed and ill-sorted clasts of all sizes and of all degrees of roundness. Even though we observed no striated clasts when we visited the type locality, Schalk (in press) reported the occurrence of numerous large distinctly striated clasts, and his observation has been confirmed by $\mathrm{H}$. Martin (personal communication). Dreikanters have also been discovered. We agree with Schalk's (in press) interpretation that the well-rounded clasts were derived from the underlying Kamtsas 
conglomerates and became striated while they were redeposited by ice and meltwater streams.

A striated pavement has not been discovered and is not even expected to exist if the Kamtsas beds were still unconsolidated at the time of the Blaubeker Glaciation. Schalk (in press) suggested that the sediment was originally deposited as till and was subsequently reworked and redeposited as an outwash sediment.

Schalk (in press) correlated the Blaubeker glaciogenic sedimentary rocks with similar beds farther in the west, called the "Buschmannsklippe Tillite» (Martin, 1965 b, p. 51).

Glaciogenic rocksintheeastern Rehoboth area

Exploratory drilling on the farm Sib 69, about $80 \mathrm{~km}$ east of Rehoboth (No. 4 in Fig. 1), has intersected sedimentary rocks strikingly similar in appearance to, and in the same stratigraphic position as, the Blaubeker Formation. This observation seems to confirm Schalk's (in press) correlation of the Blaubeker and the Buschmannsklippe beds, thus indicating a widespread pre-Damara - Nama glaciation in central South West Africa over a distance of more than $250 \mathrm{~km}$.

The »Buschmannsklippe Tillite»

Glaciogenic sedimentary rocks exist in the area south of Gobabis where they are well exposed in the valleys of the Black and White Nossob Rivers (No. 5 in Fig. 1; Martin, 1965 a, p. 125; see Fig. 5). In this area, the glaciogenic sequence has a maximum thickness of $450 \mathrm{~m}-500 \mathrm{~m}$ and thins out toward the southwest to about $150 \mathrm{~m}$ (K. Seeger, personal communication). Best exposures occur on the farm Court 32 that we visited during a field trip. Here the rock is unbedded and contains a wide variety of ill-sorted clasts of all shapes and sizes (see Fig. 5). Angular clasts predominate in the mudstone matrix and consist of quartzite, granite, amygdaloidal lava, and jasper. Faceted and well-striated clasts are common.

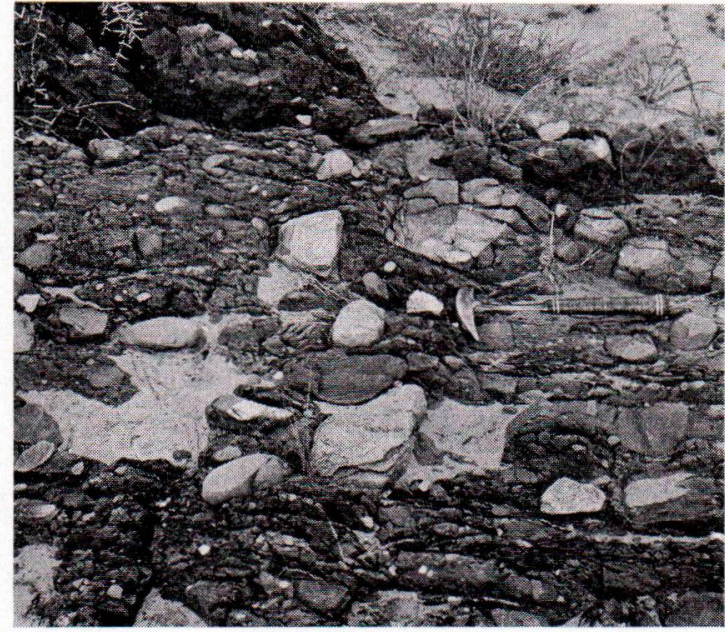

Fig. 5. Buschmannsklippe Tillite. Farm Court 32, White Nossob River, South West Africa. The rock is unbedded but shows a distinct weak foliation parallel to the handle of the hammer. Photo Alfred Kröner.

The unconformable contact with the underlying Nosib Formation results from the preBuschmannsklippe deformation, but erosion of the semiconsolidated Nosib sandstone, now a quartzite, may also have taken place (Martin, 1965 b, p. 51).

The sedimentary sequence on the farm Court 32 displays all the features charcteristic of till, and we do not hesitate to call this rock a tillite. Martin (1965 a, p. 125) regarded the rock as ground moraine because in most clasts the striations run parallel to the long axis.

South of Gobabis bedded sedimentary breccias and conglomerates occur above the Nosib strata. They may represent glacial outwash.

In the area southwest of Witvlei thick beds of mixtite strongly resemble those on the farm Blaubeker in the Rehoboth area (see p. 90), and Schalk (in press) included them in his Blaubeker Formation. These strata appear to be of fluvialglacial origin, and some scratched clasts have been observed on the farm Otjimbondona 225 (H. Martin, personal communication).

The glaciogenic sedimentary rocks described above are overlain by rocks of the Nama System. Martin (1965 b, p. 115) concluded that their con- 
tact is conformable and regarded the tillite as the basal part of his Buschmannsklippe Formation, now included in the Nama System. Structural considerations, however, indicate that the contact is paraconformable and that all the glaciogenic sedimentary rocks belong to a pre-Nama assemblage to be correlated with the Blaubeker Formation farther in the west (Schalk, in press). Inclusion of the Blaubeker - Buschmannsklippe succession into the Nosib Group has been proposed (Kröner, 1971, p. 1521).

The Nosib mixtite in the Otavi $\mathrm{High} 1 \mathrm{ands}$

The geologists of the Tsumeb Corporation have found, in the hills north of Otavi (No. 6 in Fig. 1), boulder beds overlying the Nosib quartzites that they regard as a tillite and include into the Nosib Formation. The beds are up to $40 \mathrm{~m}$ thick and contain clasts of variable shape, reaching a diameter of $60 \mathrm{~cm}$. The clasts consist of granite, gneiss, and quartzite, obviously derived from old Precambrian basement rocks, now exposed northeast of Otavi and around Grootfontein. Striated clasts or a glaciated pavement have so far not been observed, and the glaciogenic origin of the beds is consequently still doubtful. However, the stratigraphic position of the Otavi mixtite agrees with the position of the Numees, Blaubeker, and Buschmannsklippe glaciogenic rocks farther in the south, provided that the present correlations are correct. The relationship may support the conclusion that the Upper Nosib sequence is probably derived from glacial outwash and is thus of fluvial-glacial origin. The Nosib mixtite is consequently not a tillite.

\section{Glaciogenic rocks of the Nama System}

The Klein Karas Mountains "T i 11 i t e»

Schwellnus (1941) described a tillite from the Klein Karas (formerly: Kharas) Mountains (No. 7 in Fig. 1). There a mixtite occurs sporadically as a relatively thin bed, seldom more than $3 \mathrm{~m}$ and mostly about $1 \mathrm{~m}$ thick, in an area no more than $5 \mathrm{~km}$ wide and about $50 \mathrm{~km}$ long. The rock consists of an obviously reworked boulder bed with clasts of arenaceous and argillaceous shale derived from older Nama beds, dolostone, quartzite, biotite schist, and granite. Many faceted clasts and a few striated ones were reported to be present. The diameter of the clasts ranges from approximately $2 \mathrm{~cm}$ to $1 \mathrm{~m}$. The mixtite matrix consists mostly of ferruginous calcareous shale.

Schwellnus (1941, p. 24) reported also the discovery of glaciated pavements on the Kuibis Quartzite and of frequent whaleback forms in the Klein Karas Mountains. According to his observations, the Nama tillite there rests directly on such pavements.

A "glaciated" pavement is exposed on the farm Wolfschlucht 93. Here assumed glacial markings and striations (Schwellnus called them grooves) are visible on a quartzite pavement. Schwellnus (1941, pp. 26-27) thought that such markings were produced on the surface of a semiplastic or an unconsolidated rock, perhaps an incompletely consolidated sandstone, that was pushed aside or ahead by ice, thereby building up ridges along the sides or at the end of the striations. He (Schwellnus, 1941, p. 32) believed that the ice sheet moved from the north to the south.

We visited Wolfschlucht 93 in February, 1971. Because of their importance with respect to Precambrian glaciations, we discuss the assumed glaciogenic phenomena in some detail.

The particular surface that we studied has several deep striations with widely differing directions. We also observed a feature resembling a large shallow pothole. The striations on the rock surface are short, deep, and randomly oriented and very much different from glacial striations. Such scratches are known to be produced by floating drift-shod ice (Flint, 1971, pp. $90,197)$ or by stones pushed against a shore by ice floes. Nichols (1961, pp. 705-706) described, in bedrock from Arctic and Antarctic beaches, 
Holocene striations formed by sea ice and icebergs and suggested that in bedrock associated with ancient raised beaches such striations are evidence of a polar climate. The striations formed by ice push differ from glacial striations in several respects, for instance, by the fact that they are not so deep, straight, and long as are glacial striations, the prevalence of short cross striae, and the absence of chatter marks, grooves, trenches, and whaleback forms. The conclusions of Nichols were accepted by Harland, Herod, and Krinsley (1966, p. 250).

Martin (1965 b, p. 109) suggested that the striations on Wolfschlucht 93 were produced by floating and sometimes grounding ice floes. He disagreed with the presence of whaleback forms.

Our observations on Wolfschlucht 93 agree with these interpretations. Moreover, we found no striated or faceted clasts in the $»$ tillite». Because of strong reworking, the rock, in our opinion, is best described as a mixtite.

One of us (K. R.) did show a number of color slides from Wolfschlucht 93 independently to Professors J. J. Donner and Veikko Okko of the University of Helsinki. These specialists agreed that the Wolfschlucht pavement is no genuine glaciated pavement but was probably formed by boulder-shod ice floats pushing against the soft shore sediment. They agreed, however, that the grooves give evidence of a cold climate at the time of their formation. The pothole-like feature was apparently produced by flowing water.

The glacial phenomena described above occur in the Lower Schwarzrand Series of the Nama System, above a prominent unconformity (Germs, 1972, p. 68).

Possibleglaciogenic rocks north of the Huns Mountains

Two exposures of possible glaciogenic rocks on the farm Koedoelaagte (No. 8 in Fig. 1) were described by Germs (1972, p. 69). He observed deep channels cut into the so-called Huns Limestone of the Schwarzrand Series. The channelfilling sedimentary rocks, forming beds with a thickness of up to $30 \mathrm{~m}$, consist of conglomerates with fairly well-rounded clasts ranging from a few $\mathrm{mm}$ to almost one $\mathrm{m}$ in diameter. On the farm Koedoelaagte, haphazardly oriented large blocks of the Huns Limestone, up to $10 \mathrm{~m}$ in diameter, are present in the channel fill along with the conglomerate, but nowhere have striated clasts or glaciated pavements been discovered. An outcrop on the farm Inachab resembles whaleback forms, and Germs (1972, p. 69) reported that possible glacial striations have been observed on the farm Bossie. Germs (personal communication) also considered the possibility that the channel-filling deposits, which he called diamictites, are remains of outwash sediments. The evidence suggesting glaciogenic origin, however, is so meagre that we prefer to regard the channels as having been produced and filled by strong currents in a wet and, probably, cold climate. Germs (1972, p. 68) also suggested that the channels represent, within the Schwarzrand Series, an unconformity that extends as far north as beyond Helmeringhausen and that may be of tectonic and, partly, of glaciogenic origin.

Mixtite on the Orange River

Kröner and Germs (1971, pp. 71-72) described a mixtite on the farm Aussenkjer 147 (No. 9 in Fig. 1). The rock is exposed over a strike length of about $6 \mathrm{~km}$ and varies in thickness between $1.5 \mathrm{~m}$ and $11 \mathrm{~m}$. The rock is composed of numerous clasts of Schwarzkalk Limestone, up to $0.5 \mathrm{~m}$ in diameter, set in a sandy matrix ranging from calcareous to ferruginous in composition. The Aussenkjer glaciogenic beds were deposited unconformably upon the Kuibis Quartzite, and it appears that the Schwarzkalk Limestone was removed and partly incorporated in the mixtite.

Certain erosion forms on the Kuibis Quartzite on the farm Aussenkjer 147 appear to be similar to the so-called glaciated pavements of the Klein Karas Mountains, but no striated surfaces have yet been discovered. 
Possible glaciogenic rocks in the Naukluft Mountains

Korn and Martin (1959, p. 1059) described, from the Pavian Series of the Nama System in the Naukluft Mountains (No. 10 in Fig. 1), conglomerates having the appearence of glaciogenic sedimentary rocks. The matrix of these strongly folded rocks is silty or shaly, and the clasts are mostly angular, ranging from small splinters to sharp-edged plates of calcitic limestone, and to huge granite blocks, up to $6 \mathrm{~m}$ in diameter. The best exposures of the conglomerates occur on the farms Zais and Blässkrantz and along the thrust zone of the Naukluft nappes.

Originally, the Pavian conglomerates were interpreted as sedimentary breccias similar to Alpine wildflysch (Korn and Martin, 1959, p. 1059), but Martin (personal communication), having revisited the pertinent localities, now regards the glaciogenic origin of the conglomerates as distinctly possible, especially considering the other known occurrences of glaciogenic rocks in the Nama System. G. J. B. Germs (personal communication) regards the Pavian mixtites as an equivalent of the Schwarzrand glaciogenic sedimentary rocks described on pp. 92-93.

The Naukluft beds, however, may after all not be a facies of the Nama System but may represent a part of the basal Damara System (Hakos Series), thrust upon Nama sedimentary rocks (John de Villiers, personal communication). If this explanation is correct, the Pavian mixtites may be an equivalent of the Chuos glaciogenic rocks of the Damara System farther in the north.

The glaciogenic rocks at Localities $7-9$ (see Fig. 1) all belong to the Schwarzrand Series of the Nama System. Together, they may represent remnants of widespread glaciogenic strata, most of which were later reworked or completely removed by erosion.

The inferred Schwarzrand Glaciation seems to have caused a marked and widespread unconformity within the Schwarzrand Series (Germs, 1972, pp. 68-69).
The rocks at localities $7-10$ cannot be considered genuine tillites.

\section{Glaciogenic rocks of the Damara System}

The Chuos»Tillite» in the typearea

Glaciogenic sedimentary rocks were first described by Gevers (1931, pp. 5-8) from the country south of Usakos and Karibib (No. 11 in Fig. 1). He called them the "Chuos Tillite» after the Chuos Mountains where their best known exposures exist (see Fig. 6).

Mixtites are often associated with laminated shales, and the distribution of the Chuos beds is irregular and sometimes patchy. The glaciogenic sequence varies in thickness from $3 \mathrm{~m}$ to $600 \mathrm{~m}$ and is completely unbedded in this area. The unsorted clasts are of all sizes and shapes from grit to boulders up to $2.5 \mathrm{~m}$ in diameter (see Fig. 6). The boulders consist of vein quartz, basement quartzite, granite, various gneisses, and schists. Gevers (1931, p. 5) reported the presence of numerous faceted clasts. At several places, the clasts preponderate over the groundmass.

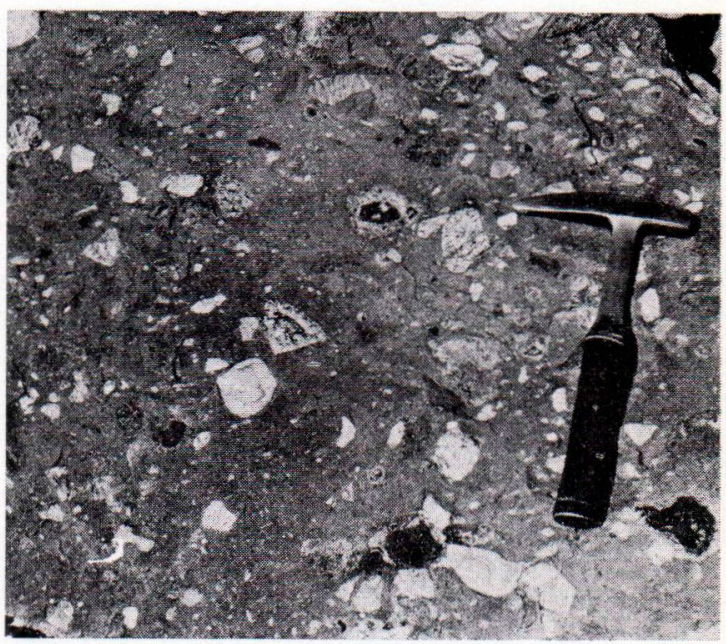

Fig. 6. Unbedded Chuos mixtite from the type locality. Farm Dorstrivier 15, south of Usakos, on the southern slope of Chuos Mountains, South West Africa. Photo Henno Martin. 
The Chuos strata are strongly folded and metamorphosed. Thereby the originally argillaceous matrix was transformed into biotite schist, whereas the arenaceous beds are now pebbly quartzites.

Smith (1965, pp. 25-27) described the Chuos glaciogenic strata discovered in the area between the Khan and Swakop Rivers where the thickness of the beds is exceedingly variable, at some places up to $700 \mathrm{~m}$, while elsewere the sequence peters out completely. Here the rocks are unbedded and have a granular or a schistose matrix. A few layers at the top of the succession contain »thinly bedded schistose metasediments, akin to varves» (Smith, 1965, p. 25). The clasts consist of gneisses, quartzites, granite pegmatites, and various schists, all believed to be derived from the pre-Damara Abbabis Formation of the basement floor. Many pebbles and boulders have been distorted into long lenticular shapes during intense deformation. Facets are therefore rare, and striations are absent.

Jacob (1972, pp. 60-61) reported the sporadic occurrence of strongly deformed Chuos mixtite, up to $250 \mathrm{~m}$ thick, in the area east of Swakopmund.

Both Gevers (1931) and Smith (1965, p. 26) suggested that a part of the Chuos glaciogenic beds constitutes, as Gevers (1931, p. 13) stated, "a typical ground-moraine of an extensive ice-sheet», especially where pre-Damara topographic depressions are filled with locally thick accumulations of till. Mostly, however, the Chuos mixtite appears to be a glacial-marine deposit (Martin, 1965 b, p. 24), because the underlying Damara beds are not disrupted and no glacial pavements are known to exist in this area.

Glaciogenic rocks southwest of Out jo

In recent years, during mapping carried out by the Geological Survey of South West Africa, the "Chuos Horizon» has been encountered at many localities (No. 12 in Fig. 1). In the miogeosynclinal northern terrain it occurs between the
Lower and the Upper Otavi Series of the Damara System, whereas farther in the south, in the eugeosyncline, it occurs in the Hakos Series.

Frets (1969, p. 106) described the glaciogenic rocks as »tilloids», without defining this term, and reported their thickness as being up to $120 \mathrm{~m}$ at Welwitschia. Subangular and ill-sorted clasts ranging from $0.5 \mathrm{~cm}$ to $50 \mathrm{~cm}$ in diameter are set in a coarse immature argillaceous sandstone that is finely laminated at some places. The "tilloid", however, is not persistent and may grade laterally into phyllite and pebbly shale. The clasts consist of various gneisses, amphibolite, schists, calcitic limestone, quartz, granite pegmatite, quartzite, and andesitic porphyry.

East of Fransfontein, along the edge of the Fransfontein basement inlier, the Chuos mixtite with clasts up to $1 \mathrm{~m}$ in diameter crops out intermittently and at places reaches a thickness of $30 \mathrm{~m}$. It is accompanied by carbonaceous shale, grit, and banded ironstone (Roy McG. Miller, personal communication).

South of Fransfontein, the "Chuos Formation». (Miller, 1972, p. 52) is generally only a few meters thick. It displays a schistose matrix and contains predominantly angular unsorted granite clasts and only a few quartzite and dolostone erratics. Locally, however, for instance, at the eastern edge of the Summas Mountains, the glaciogenic sequence may attain a thickness of $190 \mathrm{~m}$, and the matrix becomes dolomitic at the base. Clasts consisting of dolostone, quartzite, pelitic metasediments, gneiss, granite, and rhyolitic lava attain a diameter of up to $60 \mathrm{~cm}$. Two thin beds of banded ironstone, with no clasts at all, are intercalated in the sequence.

Most of the Chuos mixtite in the Fransfontein - Outjo area was probably originally a glacialmarine deposit, as evidenced by the roundness of most clasts and by the frequent intercalated schist and dolostone bands and lenses. However, Miller (1972, p. 54) regarded the thick accumulation on the Summas Mountains as consolidated till because it is unbedded and unsorted and displays a marked preponderance of angular clasts. 
Striated clasts and pavements have not been observed, evidently because of the upper greenschist-facies metamorphism imprinted on the rocks during the Damara Orogeny.

Glaciogenic rocks south of Tsumeb

Glaciogenic beds were first reported in the Otavi Mountains (No. 13 in Fig. 1) by le Roex (1941, pp. 211-216). They occur between the Upper Abenab and the Lower Tsumeb Stage of the Otavi Series (Söhnge, 1964, p. 368) and attain a maximum thickness of approximately $70 \mathrm{~m}$. North of Otavi, the glaciogenic rocks are rather unmetamorphosed but extensively folded, whereas farther in the south recrystallization has taken place, and the rocks are notably sheared.

The fine-grained matrix of the Otavi mixtite consists of varying amounts of quartz and calcite, and the clasts consist of quartzite, dolostone, chert, granite, and gneiss. Faceted clasts are common, and both striation and scouring have been locally observed (le Roex, 1941, p. 216). The diameter of the clasts varies from a few $\mathrm{mm}$ to $1 \mathrm{~m}$. No graded bedding has been observed, and the clasts are unsorted. No striated pavement underlying the mixtite has yet been discovered, because the glaciogenic rocks were largely deposited onto dolostone and calcitic limestone, but the great number of well-rounded clasts and the mixtitedolostone association suggest that the glaciogenic beds were originally not tills but rather glacial-marine deposits that were subsequently rew orked.

Glaciogenic rocks in the southern Ka okoveld

In the southern Kaokoveld (No. 14 in Fig. 1), the Chuos mixtite occurs in both the miogeosynclinal and the eugeosynclinal facies of the Damara System (Guj, 1970, pp. 10-13, 48-50). Angular unsorted polygenetic rudaceous material, cemented by a ferruginous carbonaceous or argillaceous matrix, constitutes the glaciogenic horizon that has a maximum thickness ranging from less than $1 \mathrm{~m}$ to more than $300 \mathrm{~m}$. Guj (1970, p. 13) ascribed the varying thickness to the effect of a transgressive overlap on a tilted and eroded pre-Chuos landscape and thought that the mixtite was an ice-rafted deposit.

Glaciogenic rocks in the northern $\mathrm{Ka}$ okoveld

In the northern Kaokoveld (No. 15 in Fig. 1), the well-exposed Chuos mixtite extends for about $240 \mathrm{~km}$ from Kamanjab to the Etoroha Hills (Martin, 1965 b, p. 28). It is associated with beds of shale, siltstone, and quartzite that are often iron-bearing, and the whole sequence is up to $600 \mathrm{~m}$ thick. The matrix of the glaciogenic rocks varies from calcareous to shaly, and the rounded or angular clasts, up to $1 \mathrm{~m}$ in diameter, consist of quartzite, dolostone, granite, gneiss, and diabase. Martin (1965 b, p. 28) reported faceted and striated quartzite pebbles at several localities. No striated pavement is known in this area, and the occurrence of glaciogenic material intercalated with marine sedimentary rocks suggests deposition of the original sediment as icerafted till.

The Chuos pebbly schist south of Windhoek

The area south of Windhoek (No. 16 in Fig. 1) forms the southern margin of the Damara eugeosyncline where the Hakos Series of the Damara System, including the Chuos beds, reappears under a thick pile of argillaceous sedimentary rocks (see Fig. 2).

Strong deformation and amphibolite-facies metamorphism have extensively affected this area, and the glaciogenic origin of the Chuos beds is therefore often doubtful. The assumedly glaciogenic sequence, first described by de Kock and Gevers (1932, pp. 115-116), consists of conglomerate, mixtite with boulders up to $2 \mathrm{~m}$ in diameter, phyllite, schistose quartzite, quartz 
schists, and frequent lenses of itabiritic iron ore. Ill-sorted, frequently faceted clasts occur throughout the sequence but are not abundant. According to the composition of the matrix, the rock has been called pebbly schist, pebbly biotite quartzite, pebbly phyllite, and pebbly limestone (de Kock and Gevers, 1932, pp. 116-117). Most of the clasts consist of quartzite, but clasts of porphyritic granite are also present. Where deformation has not been very pronounced, it still appears that the distribution of the clasts is erratic, that no bedding is present, and that no sorting has taken place. The laminated matrix curves frequently around isolated clasts. The thickness of the glaciogenic sequence cannot be accurately ascertained because of strong folding and faulting, but Karl Schalk (quoted in Martin, 1965 b, p. 24) reported a thickness of up to 600 $\mathrm{m}$ for the mixtite and the associated sedimentary rocks.

No striated pavement has been observed in the area discussed, and the presence of layers of pebbly calcitic limestone up to $30 \mathrm{~m}$ thick strongly suggests glacial-marine deposition.

We visited several localities southeast of Windhoek, and despite the fact that the rocks are often sheared and foliated it appeared that they are not conglomerates. Their formation as mudflow deposits is another unlikely explanation (Martin, 1965 b, p. 29). The pebbly schist was most probably originally partly a glaciogenic deposit reworked offshore and partly glacial-marine drift. However, Hälbich (1970, p. 65) regarded some parts of the Chuos Formation as englacial debris deposited near or above the highest shore line.

\section{Correlations in Africa}

Two distinct groups of glaciogenic rocks have been described in this paper. The older group (Nos. 1, 3-6 in Fig. 1) crops out in some parts of southern, central, and northern South West Africa and belongs to Late Precambrian sedimentary assemblages previously called the Nosib Formation (Martin, 1965 b, p. 36), now called the Nosib Group (Kröner, 1971, p. 1521) and the Gariep Group (Kröner, 1971, p. 1519). The younger group (Nos. 7-16 in Fig. 1) occupies a distinct stratigraphic zone in both the Damara and the Nama Systems (see Fig. 2).

In northern South West Africa, Nosib glaciogenic rocks have so far been discovered only in the Tsumeb area (No. 6 in Fig. 1) where they occur at the top of the succession (see Fig. 2). If they were ever deposited farther in the west, erosion may have removed them prior to the deposition of the sediments of the Damara System, because there the Damara overlies the Nosib unconformably, indicating a significant hiatus (Guj, 1970, p. 48).

In central South West Africa, the Blaubeker Formation (Nos. 3, 4 in Fig. 1) is the equivalent of the Buschmannsklippe glaciogenic sedimentary sequence farther in the east (No. 5 in Fig. 1), and both rock units occupy similar stratigraphic positions (Schalk, in press). Kröner (1971, p. 1521) suggested that the Blaubeker be incorporated into the Nosib Group.

In southern South West Africa, the Numees glaciogenic strata (No. 1 in Fig. 1) occur at the top of the Gariep Group (see Fig. 2). Martin (1965 b, p. 90) proposed the correlation of the basal Gariep beds (the Stinkfontein Formation) with his Nosib Formation, whereas the upper Gariep beds should be the equivalent of the Damara System. Thus, he (Martin, 1965 b, p. 116) favored the correlation of the Numees glaciogenic rocks with the Chuos mixtite. It has since been suggested, however, that the whole Gariep Group may be correlated with the Nosib Group farther in the north (Kröner, 1971, p. 1522). Consequently, all the glaciogenic rocks of the older groups (Nos. 1, 3-6 in Fig. 1) would occupy identical stratigraphic positions (see Fig. 2). If valid, this suggestion provides evidence for a widespread glaciation in most parts of South West Africa prior to the deposition of sediments of the Damara and the Nama Systems.

The correlation of the younger mixtites depends on the relationship between the Damara 
and the Nama Systems. The two rock units, unfortunately, never occur in contact, but field work in the Rehoboth area (Schalk, in press) and in the Orange River area strongly suggests that the Nama System represents the cratonic facies of the geosynclinal Damara System (Martin, 1965 b, p. 115; Kröner, 1971, pp. 1520-1522). Consequently, the Chuos mixtite is considered the equivalent of the Schwarzrand glaciogenic rocks (Nos. 7-9 in Fig. 1). This correlation, if valid, will provide evidence for a second widespread Late Precambrian glaciation in South West Africa.

No radiometric ages are yet available for the glaciogenic sedimentary rocks discussed in this paper. However, the Numees mixtite overlies felsites with a Rb-Sr whole-rock age of about 720 Ma (de Villiers, 1968, p. 34), and the postNumees Nama System is believed to be older than $550 \mathrm{Ma}$ (de Villiers and Burger, 1967, p. 84). An age of $720 \mathrm{Ma}-700 \mathrm{Ma}$ is thus likely for the first glaciation, whereas the second glaciation may have an age of approximately $650 \mathrm{Ma}$. Unfortunately, at present there exists no better evidence of the ages of the rocks.

Late Precambrian sedimentary rocks with intercalated glaciogenic, or possibly glaciogenic, beds are known to occur also in other parts of southern Africa. This fact strengthens the possibility that continentwide glaciations occurred in Africa in pre-Phanerozoic time. The Katanga Group in the Republic of Zaïre (formerly Congo Kinshasa) and in Zambia contains two horizons of generally accepted glaciogenic sedimentary rocks, namely, the Grand Conglomerat and the Petit Conglomérat (Cahen, 1963). In Katanga, the Grand Conglomérat was probably deposited as till in the north and as a fluvial-glacial, partly reworked, sequence in the south (Cahen and Lepersonne, 1967, p. 241). Binda and van Eden (in press) showed that the »Great Conglomerate» of the Copperbelt in Zambia may be considered the glacial-marine facies of the $\mathrm{Ka}$ tangan mixtite. Scanty geochronologic data indicate an age of less than $950 \mathrm{Ma}$ for the Grand
Conglomérat (Cahen, 1970, Fig. 2 and p. 105), while the Petit Conglomerat was deposited between two early phases of the Katangan Orogeny, provisionally dated at $710 \mathrm{Ma}$ ago and $670 \mathrm{Ma}$ ago, respectively (Cahen, 1970, p. 109). The apparent $\mathrm{K}-\mathrm{Ar}$ age of about $483 \mathrm{Ma}$, obtained for lavas of central Katanga that are older than the Petit Conglomérat, is much too young (Cahen and Snelling, 1971, p. 200). Martin (1965 b, p. 118) already suggested the correlation of these mixtites with the Numees and Chuos glaciogenic rocks in South West Africa.

Sedimentary rocks of unquestionable glaciogenic origin have been discovered in the Late Precambrian Sijarira Group in northwestern Rhodesia (Harper, 1970; Mann, 1971, p. 101) and may probably be correlated with the Nosib and the Katanga Groups.

Schermerhorn and Stanton (1963, p. 231), like previous geologists, equated the Lower and the Upper "Tilloids" of the West Congo System in Angola, Gabon, Zaïre, and the Congo Republic with the two Conglomérats of Katanga. Even though they regarded their stilloids" as submarine mudflow deposits, their interpretation has not been widely accepted (Cahen and Lepersonne, 1967, p. 272), and the Lower and the Upper »Tiliite Series» of the West Congo System in the Congo Republic (Congo Brazzaville; Dadet, 1969, pp. 31-32, 37-38) and in Gabon (Hudeley, 1970, pp. 54-55, 58) are now considered glaciogenic deposits.

Roland Trompette (personal communication) reported the existence of two Late Precambrian glaciations in northwestern Africa. He discovered, near Atar in Mauritania, a Late Precambrian tillite that he considered the probable equivalent of the about $620 \mathrm{Ma}$-old tillite in Ghana.

Haughton (1961) considered published information dealing with the possible Late Precambrian glaciation in the West Congo Geosyncline, in the Katanga Geosyncline, and in northern Congo in central Africa, in Mauritania, Mali, Guinea, and Ghana in western Africa, and in Angola in south- 
western Africa. He concluded that the available evidence was sufficient to justify the hypothesis of a long glaciation of semicontinental dimensions in that area. The probable coevality of all mixtites in central and southern Africa would also suggest the existence of severe climatic conditions in a large part of Africa during the Late Precambrian.

\section{The Late Precambrian glaciation in Australia and in South America}

Dunn, Thomson, and Rankama (1971) published an account of the Late Precambrian glaciation in Australia. A large part of the island continent was glaciated about $750 \mathrm{Ma}-670 \mathrm{Ma}$ ago. Evidence of the glaciation is widespread throughout the central part of Australia from the Kimberleys in northwestern Australia to South Australia and western New South Wales, and, probably, to King Island in Tasmania. The principal evidence of the glaciation is the presence of glaciogenic sedimentary rocks and glaciated pavements.

Two separate periods of glaciation are represented in Australia. The older glaciation, called the Sturtian Glaciation in southern and central Australia and the Moonlight Valley Glaciation in the Kimberleys, began about $750 \mathrm{Ma}$ ago. The younger glaciation, called the Marinoan Glaciation in the south and the Egan Glaciation in the northwest, began approximately $670 \mathrm{Ma}$ ago. The total duration of the two glaciations is estimated as about $100 \mathrm{Ma}$.

The well exposed and well documented Late Precambrian glaciogenic sedimentary rocks in Australia provide an ideal situation for the establishment of a chronostratigraphic unit. Such a unit, in fact, has been proposed for use in Australia (Dunn, Thomson, and Rankama, 1971). The widespread occurrence of Late Precambrian glaciogenic sedimentary rocks elsewhere in the Southern Hemisphere forms the basis of intercontinental correlations that might lead to the establishment of a Precambrian geochronologic unit. Because, at present, the pertinent rocks are known best in Australia, that continent will certainly serve as the basis of all correlations to be produced in the Southern Hemisphere. Roberts (1966) made the first attempt to correlate Late Precambrian (Adelaidean) sequences in Australia and in southern Africa, assuming the contemporaneity of tillites. Unfortunately, further attempts are still handicapped by the nonexistence or scarcity of age data for Late Precambrian glaciogenic rocks outside Australia.

In South America, the presence of glaciogenic sedimentary rocks has been reported among the assumedly Lower Paleozoic rocks in Brazil. Several geologists believe that glacial conditions existed from the Late Precambrian until the beginning of the Permian (Maack, 1957, pp. 547, 550, 585, 587; Salamuni and Bigarella, 1967, p. 9). However, to prove definitely the existence of a glacial environment is considered very difficult, if not impossible (Salamuni and Bigarella, 1967, p. 9). In Paraná, the so-called Iapó Tillite, of pre-Devonian age (Maack, 1957, pp. 554, 556), appears to be a mudflow deposit (Salamuni and Bigarella, 1967, pp. 9-10). Maack (1957, pp. 550, $552-553,587)$ described glaciogenic strata in the Lavras Series in Minas Gerais and in Bahia, assumedly ranging from Precambrian to Cambrian in age. However, the glaciogenic origin of the Lavras Series appears doubtful, and the deposits might be fluvial valley fillings (John de Villiers, personal communication). Additional evidence of Late Precambrian cold climate in South America may be the Puga Tillite in Mato Grosso (Almeida, 1964, p. 26).

Isotta, Rocha-Campos, and Yoshida (1969) published convincing evidence of a Late Precambrian glaciation in South America. They described, from the Jequitai Formation in central Minas Gerais in Brazil, an extensive glaciated pavement in Precambrian quartzite, directly overlain by a mixtite of probable Late Precambrian age.

Maack (1957, pp. 560, 562) mentioned the occurrence of assumedly glaciogenic sedimentary rocks at Mar del Plata on the Atlantic coast of 
the Buenos Aires Province in Argentina. He thought that they were of pre-Devonian age. One of us (K. R.) studied the so-called tillite at Mar del Plata in October, 1971. This rock, however, appears to be a conglomeratic layer in quartzite.

No doubt the next stage in the study of the Late Precambrian glaciation in the Southern Hemisphere will be the extension of correlations to cover Australia, much of Africa, and parts of South America, when the required new age data have been obtained. Dunn, Thomson, and Rankama (1971, pp. 501-502) emphasized the importance of the Late Precambrian glaciogenic sedimentary rocks for the establishment of a worldwide geochronologic unit for the Late Precambrian. Attempts are now being made to correlate the Late Precambrian glaciogenic rocks in the Northern Hemisphere with those in the Southern Hemisphere on the basis of detailed geochronologic, sedimentologic, and tectonic data, under the auspices of the International Geological Correlation Program established by the International Union of Geological Sciences and as a part of the activities of the Subcommission on Precambrian Stratigraphy of the Union.
Acknowledgments - We gratefully acknowledge the help of the office of the Geologiese Opname (Geological Survey) in Windhoek, South West Africa, offered through its Deputy Director, Mr. L. N. J. Engelbrecht, and wish to express our gratitude to Dr. Karl Schalk of that office for his pleasant company in the field and much useful information freely given. The cooperation of Professor Henno Martin of Georg-August-Universität in Göttingen, who kindly provided Fig. 6, and of Mr. G. J. B. Germs, who made available unpublished information on the Nama System, is gratefully acknowledged. Thanks are also due to Professor John de Villiers who critically read the manuscript of this paper. Professors J. J. Donner and Veikko Okko of the University of Helsinki very kindly discussed the manner of formation of the pavement on the farm Wolfschlucht 93. Professor Donner also critically read the first three chapters of this paper. Their help is thoroughly appreciated. One of us (K. R.) gratefully acknowledges a travel grant for field work in South Africa and in South West Africa received for "Project Hemispheres» from the International Geological Correlation Program of the International Union of Geological Sciences. He wishes to extend his thanks also to Professor John de Villiers and to the Precambrian Research Unit of the University of Cape Town for hospitality and for arranging a field trip to the Richtersveld and to the southern and central parts of South West Africa in February, 1971, and to the Universidad de Buenos Aires and Professor Raúl A. Zardini for hospitality and for arranging a trip to Mar del Plata in October, 1971.

\section{REFERENCES}

Almeida, F. F. M. (1964) Geologia do centro-oeste mato-grossense. Dept. Nacl. Prod. Min., Div. Geol. Mineral 215.

Binda, P. L. and van Eden, J. G. (in press) Sedimentological evidence on the origin of the Great Conglomerate (Kundelungu Tillite). Palaeogeography, Palaeoclimatol., Palaeoecol.

Boulton, G. S. (1972) Modern arctic glaciers as depositional models for former ice-sheets [Abstract]. J. Geol. Soc. London 128, p. 208.

Cahen, L. (1963) Glaciations anciennes et dérive des continents. Ann. Soc. Géol. Belg. 86. B 19.

- (1970) Igneous activity and mineralization episodes in the evolution of the Kibaride and Katangide orogenic belts of Central Africa. In: African Magmatism and Tectonics (edit. by Clifford, T. N. and GASS, I. G.) p. 97. Edinburgh.
Cahen, L. and Lepersonne, J. (1967) The Precambrian of the Congo, Rwanda, and Burundi. In: The Precambrian, Vol. 3 (edit. by Rankama, Kalervo), p. 143. New York-London-Sydney.

- and Snelling, N. J. (1971) Données radiométriques nouvelles par la méthode potassium-argon. Existence d'une importante élévation post-tectonique de la témperature dans les couches katangiennes du sud du Katanga et du Copperbelt de la Zambia. Ann. Soc. Géol. Belg. 94, p. 199.

Crawford, A. R. and Dally, B. (1971) Probable nonsynchroneity of Late Precambrian glaciations. Nature (London) 230, p. 111.

Crowell, J. C. (1964) Climatic significance of sedimentary deposits containing dispersed megaclasts. In: Problems in Palaeoclimatology, Proc. NATO Palaeoclimates Conf., 1963 (edit. by Narrn, A. E. M.), p. 86. London -New York-Sydney. 
Crowell, John C. and Frakes, Lawrence A. (1970) Phanerozoic glaciation and the causes of ice ages. Am. J. Sci. 268, p. 193.

DADET, P. (1969) Notice explicative de la carte géologique de la République du Congo Brazzaville. Bur. Rech. Géol. Minières, Mém. 70. Paris.

de Kock, W. P. and Gevers, T. W. (1932) The Chuos Tillite in the Rehoboth and Windhoek Districts, South-West Africa. Trans. Geol. Soc. S. Africa 35, p. 115.

Denton, George $H$. and Armstrong, Richard L. (1969) Miocene-Pliocene glaciations in southern Alaska. Am. J. Sci. 267, p. 1121.

de Villiers, John (1968) Sixth Annual Report, Precambrian Research Unit, Univ. Cape Town, p. 34.

- and Burger, A. J. (1967) Note on the minimum age of certain granites from the Richtersveld area. Ann. Geol. Surv. S. Africa 6, p. 83.

- and Söhnge, P. G. (1959) The geology of the Richtersveld. Geol. Surv. S. Africa, Mem. 48.

Dunn, P. R., Thomson, B. P., and Rankama, Kalervo (1971) Late Pre-Cambrian glaciation in Australia as a stratigraphic boundary. Nature (London) 231, p. 498.

Flint, R. F. (1961) Geological evidence of cold climate. In: Descriptive Palaeoclimatology (edit. by NaIrN, A. E. M.), p. 140. New York and London.

Flint, Richard Foster (1971) Glacial and Quaternary Geology. New York-London-Sydney-Toronto.

Frets, D. C. (1969) Geology and structure in the HuabWelwitschia area, South West Africa. Precambrian Research Unit, Univ. Cape Town, Bull. 5.

Germs, Gerard J. B. (1972) Preliminary report on the stratigraphy and paleontology of the Nama Group, South West Africa. In: Seventh to Ninth Annual Reports: 1969, 1970 and 1971, Precambrian Research Unit, Univ. Cape Town (edit. by DE VIlliers, John), p. 67.

Gevers, T. W. (1931) An ancient tillite in South-West Africa. Trans. Geol. Soc. S. Africa 34, p. 1.

GuJ, P. (1970) The Damara mobile belt in the southwestern Kaokoveld, South West Africa. Precambrian Research Unit, Univ. Cape Town, Bull. 8.

HÄLBICH, I. W. (1970) The geology of the western Windhoek and Rehoboth Districts: A stratigraphic-structural analysis of the Damara System. Unpublished D. Sc. Thesis, Univ. Stellenbosch, S. Africa.

Harland, W. B. (1964) Evidence of Late Precambrian glaciation and its significance. In: Problems in Palaeoclimatology, Proc. NATO Palaeoclimates Conf., 1963 (edit. by NAIrn, A. E. M.), p. 119. London-New York-Sydney.

- (1965) Critical evidence for a great Infra-Cambrian glaciation. Geol. Rundschau 54, p. 45, 1964 [Published in 1965].
Harland, W. B., Herod, Kay N. and Krinsley, D. H. (1966) The definition and identification of tills and tillites. Earth-Sci. Rev. 2, p. 225.

Harper, G. (1970) The structure and stratigraphy of the eastern portion of the Sijarira Group and associated formations in the Lower Umniati River area, Rhodesia. Unpublished Ph. D. Thesis, Univ. London.

Haughton, S. H. (1961) Review of a probable Late Precambrian glacial period in Central and West Africa. Trans. Geol. Soc. S. Africa 64, p. 73.

Hedberg, Hollis D. [Editor] (1972) Summary of an International Guide to Stratigraphic Classification, Terminology, and Usage. International Subcommission on Stratigraphic Classification, Report No. 7b. Lethaia 5, p. 297.

Heezen, Bruce C. and Hollister, Charles (1964) Turbidity currents and glaciation. In: Problems in Palaeoclimatology, Proc. NATO Palaeoclimates Conf., 1963 (edit. by Narrn, A. E. M.), p. 99. LondonNew York-Sydney.

Hudeley, H. (1970) Carte géologique de la République Gabonaise au 1/1000000, notice explicative. Bur. Rech. Géol. Minières, Mém. 72, Paris.

Isotta, Carlos A. L., Rocha-Campos, A. C., and Yoshida, R. (1969) Striated pavement of the Upper Pre-Cambrian glaciation in Brazil. Nature (London) 222, p. 466.

ЈАСов, R. E. (1972) Preliminary report on the geology of an area East of the confluence of the Khan and Swakop Rivers, S. W. A. In: Seventh to Ninth Annual Reports: 1969, 1970 and 1971, Precambrian Research Unit, Univ. Cape Town (edit. by DE Villiers, John), p. 58.

KING, L. C. (1961) The palaeoclimatology of Gondwanaland during the Palaeozoic and Mesozoic Eras. In: Descriptive Palaeoclimatology (edit. by NAIrn, A. E. M.), p. 307. New York and London.

Korn, Hermann and Martin, Henno (1959) Gravity tectonics in the Naukluft Mountains of South West Africa. Geol. Soc. Am. Bull. 70, p. 1047.

Kröner, Alfred (1971) Late-Precambrian correlation and the relationship between the Damara and Nama Systems of South West Africa. Geol. Rundschau 60, p. 1513.

- (in preparation) The Gariep Group. Precambrian Research Unit, Univ. Cape Town, Bull.

- and Germs, G. J. B. (1971) A re-interpretation of the Numees-Nama contact at Aussenkjer, South West Africa. Trans. Geol. Soc. S. Africa 74, p. 69.

LE Roex, H. D. (1941) A tillite in the Otavi Mountains, S.W.A. Trans. Geol. Soc. S. Africa 44, p. 207.

MAACK, ReINHARd (1957) Über Vereisungsperioden und Vereisungsspuren in Brasilien. Geol. Rundschau 45, p. 547 . 
Mann, Adrian Gardiner (1971) The stratigraphy and structure of the western portion of the Sijarira Group in the Lower Umniati River area, Rhodesia. Unpublished $\mathrm{Ph}$. D. Thesis, Univ. London.

Martin, Henno (1965 a) Beobachtungen zum Problem der jung-präkambrischen glazialen Ablagerungen in Südwestafrika. Geol. Rundschau 54, p. 115. 1964 [Published in 1965].

- (1965 b) The Precambrian geology of South West Africa and Namaqualand. Precambrian Research Unit, Univ. Cape Town.

McMillan, M. D. (1968) The geology of the WitputsSendelingsdrif area. Precambrian Research Unit, Univ. Cape Town, Bull. 4.

Miller, R. MCG. (1972) The geology of a portion of southern Damaraland, South West Africa, with particular reference to the petrogenesis of the Salem Granite. Unpublished Ph. D. Thesis, Univ. Cape Town.

Narrn, A. E. M. [Editor] (1964) Problems in Palaeoclimatology. Proceedings of the NATO Palaeoclimates Conference Held at the University of Newcastle upon Tyne January 7-12, 1963. London-New YorkSydney.

Nichols, Robert L. (1961) Characteristics of beaches formed in polar climates. Am. J. Sci. 259, p. 694.

Roberts, H. G. (1966) Report on a study tour of southern Africa. Bur. Mineral Resources Australia, Record 1966/ 217.

Rogers, A. W. (1915) The geology of part of Namaqualand. Trans. Geol. Soc. S. Africa 18, p. 72.

Salamuni, Riad and Bigarella, João José (1967) The pre-Gondwana basement. In: Problems in Brazilian Gondwana Geology (edit. by Brgarella, J. J., Becker, R. D., and Pinto, I. D.), p. 3. CuritibaParaná-Brazil. Also published in: Reviews Prepared for the First Symposium on Gondwana Stratigraphy, Mar del Plata, Argentina, September 1967, p. 10. International Union of Geological Sciences, Committee for the Study of Geological Documentation [Published in 1970].

SchalK, K. (in press) The »Tsumis Formation" of Central South West Africa. Ann. Geol. Surv. S. Africa.
Schermerhorn, L. J. G. (1966) Terminology of mixed coarse-fine sediments. J. Sediment. Petrol. 36, p. 831.

Schermerhorn, Lodewijk Jakob Gerard and Stanton, William Iredale (1963) Tilloids in the West Congo Geosyncline. Quart. J. Geol. Soc. London 119, p. 201.

Schwarzbach, M. (1961) The climatic history of Europe and North America. In: Descriptive Palaeoclimatology (edit. by NaIrN, A. E. M.), p. 255. New York and London.

- (1964) Criteria for the recognition of ancient glaciations. In: Problems in Palaeoclimatology, Proc. NATO Palaeoclimates Conf. 1963 (edit. by NAIrN, A. E. M.), p. 81. London-New York-Sydney.

Schwellnus, C. M. (1941) The Nama Tillite in the Klein Kharas Mountains, S. W. A. Trans. Geol. Soc. S. Africa 44, p. 19.

Sмrth, D. A. M. (1965) The geology of the area around the Khan and Swakop Rivers in South West Africa. Geol. Surv. S. Africa Mem. 3 (South West Africa Series).

Söhnge, P. G. (1964) The geology of the Tsumeb mine. In: The Geology of Some Ore Deposits in Southern Africa (edit. by Haughton, S. H.) Vol. 2, Geol. Soc. S. Africa, p. 367.

Spencer, Anthony Mansell (1971) Late Pre-Cambrian glaciation in Scotland. Mem. Geol. Soc. London 6.

Winterer, Edward L. (1964) Late Precambrian pebbly mudstone in Normandy, France: tillite or tilloid? In: Problems in Palaeoclimatology, Proc. NATO Palaeoclimates Conf., 1963 (edit. by NAIrn, A. E. M.), p. 159. London-New York-Sydney.

Young, Grant M. (1970) An extensive Early Proterozoic glaciation in North America? Palaeogeography, $\mathrm{Pa}-$ laeoclimatol., Palaeoecol. 7, p. 85.

A slightly different version of this paper was published, with limited circulation, as Bulletin 11 of the Precambrian Research Unit, University of Cape Town, South Africa.

Manuscript received, September 5, 1972. 